\title{
The Role of the Judiciary: From Marbury to Anderson
}

\author{
Donald R. Wright*
}

\section{Editor's Note}

The following Article was prepared as the third annual Roger J. Traynor Lecture at Boalt Hall School of Law. It was completed before the United States Supreme Court decisions on the death penalty in Furman v. Georgia, decided on June 29, 1972. Although the United States Supreme Court did not hold the death penalty unconstitutional per se, it did in five separate opinions invalidate the sanction as currently administered. Thus, the California supreme court once again presaged a United States Supreme Court decision, fulfilling the innovative role that Chief Justice Wright describes in his speech.

I am honored to have been selected to dehiver the third annual lecture in a series named after my predecessor, Chief Justice Roger J. Traynor. As a member of our court for nearly thirty years, he wrote some 900 opinions; many of them remain landmark decisions not only in this state but im all jurisdictions where Anglo-American jurisprudence prevails. ${ }^{1}$ As my colleague Justice Mathew Tobriner wrote: "It is remarkable, . . that over a span of thirty yearsa period of enormous change in both social conditions and judicial doctrines that reflected them-Traynor retained a sensitivity to the need for legal reforin. He never becaine a prisoncr of dogma but gave legal vitality to new approaches over the widest spectrum of social ills."2 Several of Chief Justice Traynor's decisions will be considered later.

I am also pleased to have this opportumity to speak to you on what is the most fundamental of all legal concepts in our constitutional form of government. Although adherence to this principle is basic to the preservation of our form of government, it has recently been pilloried, challenged and attacked, frequently under color of chainpionmg the people's cause. I refer, of course, to judicial review of legislative actions. I do not claim the infallibility of court decisions that condemn particular legislation. Some such decisions, I am certain, are

* Chief Justice, Supreme Court of California.

1. See Tobriner, Chief Justice Roger Traynor, 83 HARv. L. REv. 1769 (1970).

2. Id. at 1770-71. 
written in good faith error, and men of integrity are always compelled to express their differing views on the merits of court action. Such attacks on the correctness of certain decisions invalidating legislation caution me to exercise greater care but do not disturb me. I am disturbed, however, by attacks that go beyond the merits of issues and clallenge the compulsion imposed upon the court and even the court's right to examine and reexamine legislation in light of prevailing constitutional tests.

As every student of American history knows, governmental oppression led in 1776 to the Declaration of Independence, which recognized the natural rights of citizens and the limited rights of government. In order to secure the truths declared in that document to be self-evident, it was recognized that "governments are instituted among men, deriving their just powers from the consent of the governed."

The Revolution followed, and at its conclusion the new states negotiated for the establishment of a common government. Their first attempt, the Articles of Confederation in 1781, was a dismal failure. The hard lessons that the colomists had learned made them cautious, and they withheld such significant powers from the central government that it was rendered impotent. ${ }^{3}$ As Congress spoke in feebler tones, the state governments becaine contemptuous of the national assembly and "violated the Articles of Confederation by ignoring the nation's treaties with foreign countries, by waging war with the Indians, [and] by building navies of their own." They sent men of narrow vision and of dubious ability "to represent them [in Congress,] and at times failed to send anyone." 4 In fact, respect for the national legislative body so deteriorated that Congress was frequently unable to muster a quornm.

In the vacuum left by the absence of a more powerful central government, the states grew stronger and became less responsive to the people. Each state began exercising its exclusive right to regulate commerce within its borders in a manner calculated to gain advantage over its neighboring states. Furthernore, to worsen an intolerable situation, foreign countries violated treaties with the states, and bands of malcontents threatened armed insurrection. ${ }^{6}$

It was under these conditions that the leaders of the Revolution reconvened to examine the viability of the system established by the Articles of Confederation. After concluding that the Articles were

3. 1 J. BRYCE, THE AMERICAN COMMONWEALTH 20-21 (3d ed. 1909).

4. E. S. MORGaN, THE BIRTH OF THE REPUBLIC, 1763-1789, 125 (1956).

5. Id.

6. $1 \mathrm{H}$. von Holst, The Constitutional and Political History of the UNTted States 40-42 (1889). 
beyond resuscitation, they drafted an entirely new body of organic law-the Constitution.

The framers of the Constitution had two paradoxical objectives: first, to create a durable central government that would mold the separate states into a federal union; and second, to limit that government by reserving certam rights to the states and the people. To accomplish these ends, the framers returned to the writings of Locke and Montesquieu, the same sources used in drafting the Declaration of Independence. These philosopliers, who espoused theories of social contract, also advocated systems for the separation of powers designed to protect the natural rights of every person. The framers adapted the separation of powers theory to their needs and wrote it into the Constitution. ${ }^{7}$ They declared that Congress could legislate only for the purposes specified or implied in the Constitution and that, in legislating for permissible purposes, Congress could "not transgress any provision of the Constitution itself."

But several questions presented by the separation of powers doctrine remained unanswered: Who was to enforce the limitations imposed on the legislature by the Constitution? And, if the separation of powers was to be mamtamed, who would check the legislature when that branch imtentionally or inadvertently usurped a power that had been delegated to another governmental agency or reserved by the people?

In his landmark opinion, Marbury v. Madison, ${ }^{\circ}$ Chief Justice John Marshall confronted and resolved these problems. The dilemma, as Marshall saw it, was whether a legislative act, repugnant to the Constitution, could become the law of the land. ${ }^{10}$ To resolve this dilemma, Marshall reasoned that the framers intended the Constitution to be the "fundamental and paramount law of the nation." wrote:

It is . . . the province and duty of the judicial department, to say what the law is. Those who apply the rule to particular cases must of necessity expound and interpret that rule. If two laws conflict with each other, the courts must decide on the operation of each. [This is so] if a law be in opposition to the constitution; if both the law and the constitution apply to a particular case ... the court

7. C. Swisher, The Growth of Constitutional Power in the UNIted STates 19 (2d ed. 1963).

8. $1 \mathrm{~J}$. Bryce, The American Commonwealth 242 (3d ed. 1909).

9. 5 U.S. (1 Cranch) 137 (1803).

10. Id. at 176 .

11. Id. at 177.

12. Id. at 177-78. 
must determine which of these conflicting rules governs the case. This is of the very essence of judicial duty.

If then, the courts are to regard the constitution, and the constitution is superior to any ordinary act of the legislature, the constitution, and not such ordinary act, unust govern the case to which they both apply. Those, then, who controvert the principle that the constitution is to be considered, in court, as a paramount law, are reduced to the necessity of maintaining that courts must close their eyes on the constitution, and see only the law.

... [They] would declare that if the legislature shall do what is expressly forbidden, such act, notwithstanding the express prohibition, is in reality effectual. [This declaration] would be [giving] to the legislature a practical and real omnipotence with the same breath which professes to restrict their powers within narrow limits. ${ }^{13}$

With these words, Chief Justice Marshall announced the doctrine of judicial review. Although this principle has ever since been respected as "a permanent and indispensable feature of our constitutional system," 14 d do not urge its continuation on that basis alone; rather, I prefer also to inquire into its continued validity as a juridical concept.

Critics of judicial review in California often ask, "Why should a majority of seven justices appointed generally for long terms be permitted to outlaw the acts of elected officials?" As Profcssor Rostow has said, these critics urge that, as "an undemocratic shoot on an otherwise respectable tree," judicial review should be "cut off, or at least kept pruned and inconspicuous."15

This approach embraces a simple and unsophisticated concept of democracy wherein the government's only function is to effectuate the majority will. Personally, I view democracy as being much more complicated. The Constitution envisions that democracy includes the right of the minority to dissent in an orderly fashion. Democracy also is the right of the minority to atteinpt to become the majority. And a constitutional democracy recognizes the right of the minority to be protected from the arbitrariness or, in some instances, the tyranny of the inajority. When forces within our system would abridge these rights, the court unust intervene and protect those who have proved unable to protect themselves. In this context, judicial review of legislative acts may run counter to the will or the wish of the majority, but to say that judicial review is undemocratic is to ignore fundamental rights guaranteed to all, including the members of the minority.

13. Id. at 178.

14. See Cooper v. Aaron, 358 U.S. 1, 17-19 (1958).

15. Rostow, The Democratic Character of Judicial Review, 66 HARv. L. REv. 193 (1952). 
The Constitution is a statement of principles designed to allocate powers between the people and their government. The provisions of that document set forth a system of "enduring general values,"16 and perhaps we can describe judicial review as "institutionalized selfcontrol."17 As Lord Bryce said, the court when exercising powers of judicial review is functioning as the conscience of a people "who have resolved to restrain themselves from hasty or unjust action by placing their representatives under the restrictions of a permanent law."18

It is important to realize that legislators frequently act under pressure for immediate results, and considerations of expediency must often dominate their decisions. This is not necessarily improper and indeed is often imperative. In the legislative assemblies the demands and excitement of the moment may occasionally becloud important long-term considerations. And because legislative analysis often deals with abstract and future probleins, legislative actions sometimes have unanticipated and unintended side effects.

In the early sixties, for example, a highly dedicated and well motivated California civic organization led a campaign to eliminate drug abuse by demanding that the criminal penalties for possession, use and sale of illegal narcoties be greatly increased. The legislature responded to what it interpreted as a popular mandate and amended various sections of the Health and Safety Code. For example, the legislature rewrote section 11530.5 to provide that any person who has been convicted twice for crimes connected with illegal drugs or narcotics inust, upon a subsequent conviction for possession of marijuana, be innprisoned for from 10 years to life with no possibility of parole until 6 years of the sentence had been served. ${ }^{19}$ And to make certain that members of the judiciary, independent by nature, would not be inclined to reduce the severity of the penalty, judges were prohibited froin striking any allegation of a prior conviction even in the most meritorious case without first bargaining with and securing the consent of the prosecutorial agency. ${ }^{20}$ This provision, of course, the California supreme court recently struck down on separation of powers grounds in People $v$. Tenorio, ${ }^{21}$ a unanimous opinion authored by Mr. Justice Peters.

Now, only eleven years after this amendment was adopted, numerous blue ribbon commissions have recommended that drug abuse be treated as a medical rather than a penal problem, and the President's

16. See A. Bickel, The Least Dangerous Branch 24, 27 (1962).

17. See C. Black, The People aNd the Court 107 (1960).

18. $1 \mathrm{~J}$. BRYCE, The AMRricaN COMMONWEALTH 272-73 (3d ed. 1909).

19. CAL. H. \& S. CODE, \& 11530.5 (West 1964).

20. See CAL. H. \& S. CoDE, $\$ 11718$ (West 1964).

21. 3 Cal. 3d 89, 473 P.2d 993, 89 Cal. Rptr. 249 (1970). 
special commission has reported that 24 million Americans have experimented with marijuana. ${ }^{22}$ The possibility that long prison terms would be mandated for great numbers of individuals convicted of drug offenses was not even considered at the time of the adoption of the statute embracing the imcreased penalty.

In some instances, legislative acts either directly or indirectly affect interests that are not adequately represented in the legislature. When a pohtically impotent minority is the victim of repressive legislation, the normal electoral safeguards against legislative abuse are necessarily non-existent. Furthermore, implementation of the legislative act may tend to reduce the already limited political effectiveness of the forces that could be expected to fight for repeal or modification of unfair legislation. For example, had the Supreme Court not intervened in the apportionment cases of the 1960's and adopted the one man, one vote primciple, ${ }^{23}$ the ill-constituted legislatures that existed then would certainly still exist today. ${ }^{24}$

A democratic government must do more than serve the immediate needs of a majority of its constituency-it must respect the "enduring general values"25 of the society. Somehow, a democracy must tenaciously cling to its long-term concepts of justice regardless of the vacillating feelings experienced by a majority of the electorate.

In my opinion, in our system only the judiciary can guarantee that "general values" will endure and that the rights of all, mcluding those of politically impotent minorities, will be protected as the Constitution requires. Compared to legislators, judges are less influenced by the elective process and are generally more insulated from the transitory public whim. Additionally, a reviewing court is confronted with the equities and realities in a way uncommon in either the legislative or executive branch of the government. Having the flesh and bones of an actual case before it, a court can see how a law has worked and whether that law has created unforeseen effects which are constitutionally impermissible. Fimally, and most importantly, a court must reconsider a law every time a litigant interposes a constitutional challenge. However much we may wish to iguore such a challenge, we cannot do so and remain faithful to our oath. A court cannot wait until the public pressure which instigated passage of a particular law has subsided or until enough energy has becn generated for repeal of a particular piece

22. See San Francisco Chronicle, March 23, 1972, at 13, col. 1 .

23. Gray v. Sanders, 372 U.S. 368, 381 (1962); see also Reynolds v. Sims, 377 U.S. 533, 554-61.

24. Cf. Choper, On the Warren Court and Judicial Review, 17 CATH. U.L. REv. 20, 30-32 (1967).

25. See A. Bickel, The Least Dangerous Branch 24, 27 (1962). 
of legislation. These are all cogent reasons why the judiciary must occasionally pronounce a legislative enactment unconstitutional even when to do so may violate majority sentiment on the narrow issues.

Nevertheless, as Professor Charles Black has poimted out, ${ }^{20}$ judicial review is not merely a technique employed to protect minority rights. By stabilizing society, judicial review benefits the majority as well. Professor Black explains that by reviewing the constitutionality of legislation, the court performs a "legitimating function" in addition to its more familiar "checking function." As long as the court retains and exercises its power to strike down legislation which does not meet constitutional standards, the decision to uphold a law assures the minority that a momentary interest, not a fundamental principle, is at issue. Thus, by "legitimating" a law, the court encourages the minority to acquiesce in the law's validity and to comply with its terms.

The Constitution, then, is an enduring but evolving statement of general values designed to limit governmental action and protect individual rights. After the nonjudicial branches of government enact and enforce a law, thereby indicating their belief that the law is constitutional or that constitutionality is not their concern, the court must review the law to determine whether it does, in fact, meet constitutional standards. By observing this cautious, often burdensome and sometimes unpopular procedure, the courts can often prevent the will of the majority from unfairly interfering with the rights of individuals who, even when acting as a group, may be unable to protect themselves through the political process. In this way, judicial review assures a government under the laws. As Professor Jesse Choper has suggested, if we "[r]emove this avenue for protection of the constitutional rights of the individual .... the fight, inherently incapable of being waged in the legislative halls, has only one remaining battleground. That is the streets. The alternatives to careful judicial review are either disobedience of the law . . . or complacent acceptance . . . . Both alternatives-violence and decadence-are intolerable." 27 In short, the court today must continue to adhere to the central principle of Marbury v. Madison as enunciated by Chief Justice Marshall approximately one hundred and seventy years ago. ${ }^{28}$

Pursuant to the principle announced in the Marbury case and with respect for the rationale behind judicial review, the California supreme court recently held the death penalty unconstitutional. ${ }^{20}$ Although some

26. C. Black, The People AND the Court, 34 et seq. (1960). $20,43$.

27. Choper, On the Warren Court and Judicial Review, 17 CaTH. U.L. Rev.

28. See Marbury v. Madison, 5 U.S. (1 Cranch) 137 (1803).

29. People v. Anderson, 6 Cal. 3d 628, 493 P.2d 880, 100 Cal. Rptr. 152 (1972). 
commentators and political figures have criticized this decision by saying that the court usurped the legislative function, this criticism in my opinion is incorrect and misleading. Not only does our system obligate courts to review the constitutional validity of legislation, but our court has a history of meeting that obligation. As the examples I will mention demonstrate, the California supreme court has traditionally accepted its responsibility to protect the rights of all citizens, and especially of politically impotent minorities, by invalidating legislation which contravened constitutional standards. In fact, many of the courts opinions have marked paths which the high federal bench and other courts have subsequently followed.

In 1920, the California supreme court was confronted with an ordinance that prohibited the display or possession of any flag representing an organization that "espoused theories of government antagonistic to the Constitution or laws of the United States." 30 Our court invalidated this ordinance on the theory that people have a constitutional right to advocate changes in the Constitution or government and that people nnay possess or display flags signifying their beliefs. ${ }^{31}$ This decision recognized that symbolic speech is protected by the first amendment.

Ten years later, the Umited States Supreme Court vindicated our position by partially invalidating a similar statute on a similar theory. ${ }^{32}$ As we know from more recent opinions, the notion of symbolic speech las been invoked to protect the rights of school children in West Virginia in the pledge of allegiance case ${ }^{33}$ and, in Tinker v. Des Moines Independent Community School District, ${ }^{34}$ to protect the rights of sclool children in Iowa who wore black armbands as a symbolic protest.

In 1946, our court's landmark case, Danskin v. San Diego Unified School District, ${ }^{35}$ further solidified the rights of free speech and asseinbly for political dissenters. An act required that school boards allow free use of school auditoriums for public meetings but prohibited use by organizations seeking forcible overthrow of the governinent. Pursuant to this act, the San Diego Civil Liberties Committee was denied use of a school auditorium because its representatives refused to sign an affidavit of nonadvocacy of and nonaffiliation with subversive organizations. Writing for the court, then Associate Justice Traynor declared parts of the legislation invalid, saying:

30. In re Hartman, 182 Cal. 447, 448, 188 P. 548, 548 (1920).

31. Id. at $449,188 \mathrm{P}$. at 548 .

32. See Stromberg v. California, 283 U.S. 359, 369-70 (1931).

33. Board of Education v. Barnette, 319 U.S. 624, 633, 642 (1943).

34. 393 U.S. 503, 508-11 (1969).

35. 28 Cal. $2 \mathrm{~d} 536,171$ P.2d 885 (1946). 
It is true that the state need not open the doors of a school building as a forum and may at any time choose to close them. Once it opens the doors, however, it cannot demand tickets of admission in the form of convictions and affiliations that it deems acceptable. ... Since the state cannot compel "subversive elements" directly to renounce their convictions and affiliations, it cannot make such a renunciation a condition of receiving the privilege of free assembly in a school building. ${ }^{36}$

In Perez $v$. Sharp, ${ }^{37}$ Justice Traynor wrote another incisive opinion. In 1948, amidst public outcry and indignation, he declared that a state statute forbidding interracial inarriage was unconstitutional. Ten years later, the state legislature repealed this offensive statute, ${ }^{38}$ and twenty years later, in Loving $v$. Virginia, ${ }^{39}$ the United States Supreme Court followed California's lead and ruled that all anti-miscegenation laws violate both equal protection and due process.

In 1952, the California supreine court was called upon to prevent application of another oppressive and unfair California law-the Alien Land Law. ${ }^{40}$ The Act provided that, with certain limited execptions, aliens who were ineligible for citizenship under existing federal law could not acquire real property. Although our court had previously upheld this enactment on the theory that maintenance of land title in persons who were eligible for citizenship would promote internal security, after reconsideration we found the law to be unconstitutional. As Chief Justice Gibson reasoned in his plurality opinion, although Japanese were not singled out by name for discriminatory treatment in the land law, the reference therein to federal standards for naturalization which excluded Japanese operated automatically to bring about that result. ${ }^{41}$ The law was obviously designed and adıninistered as an instrument for effectuating racial discrimination, and the most searching examination could disclose no circumstances justifymg classification on that basis. There was nothing to indicate that those alien residents who were racially ineligible for citizenship possessed characteristics which would endanger the legitimate interests of the state, or that they, as a class, might use the land for purposes injurious to public morals, safety, or welfare. ${ }^{42}$

Two months after the California supreine court invalidated the Alien Land Law, Congress enacted a statute declaring that "The right

36. Id. at 546-47, $171 \mathrm{P} .2 \mathrm{~d}$ at $891-92$.

37. 32 Cal. 2d 711, 198 P.2d 17 (1948) (plurality opinion),

38. See CAL. Civ. CoDE, $\& 60$ (West 1961) (repealed 1959).

39. 388 U.S. 1 (1967). ion).

40. See Sei Fujii v. State, 38 Cal. 2d 718, 242 P.2d 617 (1952) (plurality opin-

41. Id. at 729,242 P.2d at 625 .

42. Id. at $737-38,242 \mathrm{P} .2 \mathrm{~d}$ at 630 . 
of a person to become a naturalized citizen . . . shall not be denied or abridged because of race. . .."43 Enactment of this statute achieved indirectly what our court achieved directly.

Nevertheless, our court was again obliged to intervene in the case of Mulkey v. Reitman ${ }^{44}$ to frustrate renewed attempts to control the distribution of real property along racial lines. Between 1959 and 1963, the California legislature enacted several statutes-imcluding the Rumford Fair Housing Act-designed to eliminate racial discrimination in housing. In 1964, however, a substantial majority of the voters approved an initiative measure known as Proposition 14 which amended the state Constitution to guarantee property owners absolute discretion in choosing ainong prospective buyers and renters. When a black couple coinplained that an apartment house owner had refused to rent thein an available apartment because of racial considerations, our court held that Proposition 14 violated the equal protection clause of the 14th ainendinent. We said that, in view of the historical context, Proposition 14 was designed to overturn laws that prohibited discrimination and therefore it invalidly gave state "encouragement" to racial discrimination. ${ }^{45}$ We found no significance in the fact that the electorate, rather than their representatives, had approved the legislation. On review, the United States Supreme Court upheld our decision. ${ }^{46}$ Furthermore, in a subsequent case concerning a public entity's attempt to nullify anti-discriminatory legislation, the high federal bench reached a similar result. ${ }^{47}$

Turning to a case decided within the past year, we were confronted in Sailer Inn v. Kirby ${ }^{48}$ with a state statute prohibiting women (other than female bar owners and wives of male bar owners) from tending bar. Reasoning that sex is a constitutionally suspect classification and that employment is a fundamental interest, we ruled that the statute would be subjected to strict scrutiny. Since our examination did not reveal a compelling justification for this discrimination against female bartenders, we struck down the statute as being violative of equal protection. Thus, we announced that women seeking employment should be judged solely according to individual merit unless sex would be an absolute impediment to effective perfornance. In the words of Justice Peters:

The desire to protect women from the general hazards inherent in many occupations cannot be a valid ground for excluding thein from

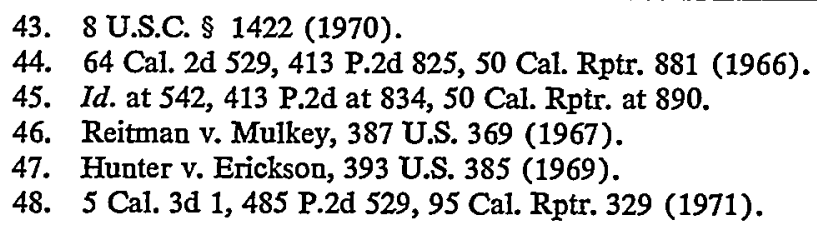

48. 5 Cal. 3d 1, 485 P.2d 529, 95 Cal. Rptr. 329 (1971). 
those occupations .... Such tender and chivalrous concern for the well-being of the female half of the adult population cannot be translated into legal restrictions on employment opportunities for women. . . .99 The pedestal upon which women have been placed has all too often upon closer inspection been revealed as a cage. ${ }^{60}$ Although I cannot claim that our opinion in Sail'er Inn was a motivating factor, I notice that Congress has proposed and sent to the states for ratification a constitutional amendment which would prohibit sexual discrimination just as other amendinents forbid discrimination on the basis of other immutable and stigmatized traits.

Also within the past year, we were called upon to determine whether the California public school fimancing system, with its substantial dependence on local property taxes and resultant wide disparities in school revenue, violates equal protection. In Serrano $v$. Priest, ${ }^{51}$ we said that classification according to wealth is highly suspect ${ }^{52}$ and that education is a fundamental interest. ${ }^{53}$ We took judicial notice that, because of disparities in property values, wealthier districts such as Beverly Hills, although taxed at half the rate, produced twice as much revenue per student as poorer districts such as Baldwin Park. ${ }^{54}$ Finding no compelling state interest to justify such unequal expenditures for education, ${ }^{65}$ we concluded that the classifications imposed by the challenged system are especially imvidious because they deprive poor children of the very means needed to escape "the vicious cycle of poverty."

Thus, the court intervened to protect minority interests that were neglected by the political process. Just as the court has struck down legislation which unconstitutionally penalized people for their political beliefs, race, national origim, and sex, so the court struck down legislation which unconstitutionally discriminated on the basis of wealth. It was with this tradition that we heard Robert Anderson's automatic appeal from a judgment sentencing him to die in the gas chamber. ${ }^{67}$

At the outset of our analysis in People $v$. Anderson, we noted that the California constitution-unlike the Federal Constitution-prohibits the infliction of "cruel or unusual" punishment. ${ }^{58}$ Reviewing the

49. Id. at 9-10, 485 P.2d at 534, 95 Cal. Rptr. at 334 .

50. Id. at 20, 485 P.2d at 541, 95 Cal. Rptr. at 341 .

51. 5 Cal. 3d 584, 487 P.2d 1241, 96 Cal. Rptr. 601 (1971).

52. Id. at 597, $487 \mathrm{P} .2 \mathrm{~d}$ at $1250,96 \mathrm{Cal}$. Rptr. at 610 .

53. Id. at 608-09, 487 P.2d at 1258, 96 Cal. Rptr. at 618.

54. Id. at 594, 611, 487 P.2d at 1248, 1260, 96 Cal. Rptr. at 608, 620.

55. Id. at 614,487 P.2d at 1263, 96 Cal. Rptr. at 623.

56. Note, Serrano v. Priest: The End of an Era in Public School Financing, 23 HAST. L.J. 365, 377 (1972). (1972).

57. See People v. Anderson, 6 Cal. 3d 628, 493 P.2d 880, 100 Cal. Rptr. 152

58. Id. at 634,493 P.2d at 883,100 Cal. Rptr. at 155 . 
history of the California provision, we concluded that the delegates to the California Constitutional Convention of 1849 who first adopted the section purposely used the disjunctive form. ${ }^{59}$ Because the federal Constitution speaks only of punishment which is both cruel and unusual, we recognized that there might be no final judicial disposition in the cases of the 104 persons under sentence of death in California until the state constitutional question was decided. We also recognized that these people were our responsibility. They had committed crimes in California, had been adjudged guilty in California, had been sentenced to death in California, were imprisoned in California, and were to be executed in California under the laws of California. Our duty was to resolve the constitutional question, regardless of its difficulty or magnitude. That was the very core of our judicial responsibility. We could not, in good conscience, avoid the problem by deferring to any other court or any other branch of governinent. ${ }^{60}$

And so we addressed ourselves to the precise issue of whether the death penalty is cruel or unusual. First assessing the cruelty of capital punishment, we stressed that the Constitution is not a static document. Judgments of the nineteenth century as to what constitutes cruelty are today of questionable viability. Were the standards of another age the constitutional measure now, whipping, branding, pillorying, severing or nailing of the ears, and boring of the tongue-all of which were once practiced forms of punishment in this country-would escape constitutional proscription. No one today would argue that such punishments are not cruel. The constitutionality of a punishment must surely be construed in accordance with contemporary standards of decency ${ }^{61}$

In assessing whether capital punishment is consonant with conteinporary standards, public attitude is inost certainly relevant, but it cannot be the controlling factor. Public attitude, however,

cannot be measured by the existence of death penalty statutes or by the fact that some juries impose death on criminal defendants. Nor are public opinion polls about a process which is far removed from the experience of most people helpful in determining whether capital punishment would be acceptable to an informed public were that penalty even-handedly applied to a substantial proportion of the persons potentially subject to execution. ${ }^{62}$

Although death penalty statutes do remain on the books of many jurisdictions, and public opinion polls do show opinion to be divided regarding capital punishment as an abstract proposition, the fact is that

59. Id. at 636-37, 493 P.2d at 885-86, 100 Cal. Rptr. at 157-58.

60. Id. at 640, 493 P.2d at 887, 100 Cal. Rptr. 159.

61. Id. at $647-48,493 \mathrm{P} .2 \mathrm{~d}$ at 893, $100 \mathrm{Cal}$. Rptr. at 165 .

62. Id. at 648,493 P.2d at 893-94, 100 Cal. Rptr. at 165-66. 
people in our state, our nation and around the world who are called upon to impose or carry out the death penalty are repudiating it with everincreasing frequency ${ }^{63}$ They recognize that the pain incident to execution is not the only cruelty. The lengthy imprisonment prior to execution has a dehumanizing effect, and it is no answer to say that the convicted person's insistence on receiving due process of law has caused the delay. ${ }^{64}$ On these bases, we concluded that continuation of the death penalty would demean the dignity of the individual and society while imposing an impermissibly cruel punishment. ${ }^{65}$ We also concluded that capital punishment was neither necessary nor sufficient to achieve rehabilitation, isolation, or deterrence-the traditional justifications for imposing punishment. ${ }^{66}$

Nevertheless, we said, if any doubt remained as to the cruelty of the death penalty, no uncertainty could renrain as to its unusualness. We could no longer uphold the death penalty on the ground that capital punishment is commonly accepted anong civilized societies, for the world-wide trend is to repudiate it. In America, a growing mimority of jurisdictions have abolished or severely restricted capital punishment, and the states where capital punishment is inaintained have bypassed this alternative in all but ten cases after 1964; no executions at all have been carried out since 1967.67

For these reasons, we held that capital punishment is both cruel and unusual and that the death penalty may not be imposed in California. As we said: "Our conclusion is not grounded in sympathy for those who would commit crimes of violence, but for the society that diminishes itself whenever it takes the life of one of its meinbers."

I believe that the founding fathers would have applauded our recognition that we were duty-bound to decide People v. Anderson. As stated in Marbury v. Madison and implemented throughout our history, the court's function is to assure adherence to constitutional principles by reviewing legislative acts. This is what we did in People v. Anderson. Nothing inore. You may, if you wish, disagree with us on the merits, but you should not challenge our right and our duty to make the determinations on the constitutional problem with which we were confronted.

I will close by recalling the words of Chief Justice Earl Warren: "The provisions of the Constitution are not time-worn adages or hollow

63. Id. at 648,493 P.2d at 894,100 Cal. Rptr. at 166.

64. Id. at 649-50, 493 P.2d at 894-95, 100 Cal. Rptr. at 166-67.

65. Id. at 650, 493 P.2d at 895, 100 Cal. Rptr. at 167.

66. Id. at 651-53, 493 P.2d at 895-97, 100 Cal. Rptr. at 167-69.

67. Id. at $653-56,493 \mathrm{P} .2 \mathrm{~d}$ at 897-99, $100 \mathrm{Cal}$. Rptr. at 169-71.

68. Id. at 656, 493 P.2d at 899, 100 Cal. Rptr. at 171. 
shibboleths. They are vital, living principles that authorize and limit governmental powers. . . . They are the rules of government." When the constitutionality of any legislative act is challenged in our courts, we must apply those rules. If we do not, "the words of the Constitution become little more than good advice." When it appears that a legislative act conflicts with a constitutional provision, "we have no choice but to enforce the paramount commands of the Constitution. . . . We cannot push back the limits of the Constitution inerely to accommodate challenged legislation. We must apply those limits as the Constitution prescribes them, bearing in mind both the broad scope of the legislative direction and the ultimate responsibility of constitutional adjudication. We do well to approach this task cautiously . . . . But the ordeal of judgment cannot be shirked." ${ }^{\prime \prime}$ added).

69. Trop v. Dulles, 356 U.S. 86, 103-04 (1958) (plurality opinion) (emphasis 